This item was submitted to Loughborough's Institutional Repository (https://dspace.lboro.ac.uk/) by the author and is made available under the following Creative Commons Licence conditions.

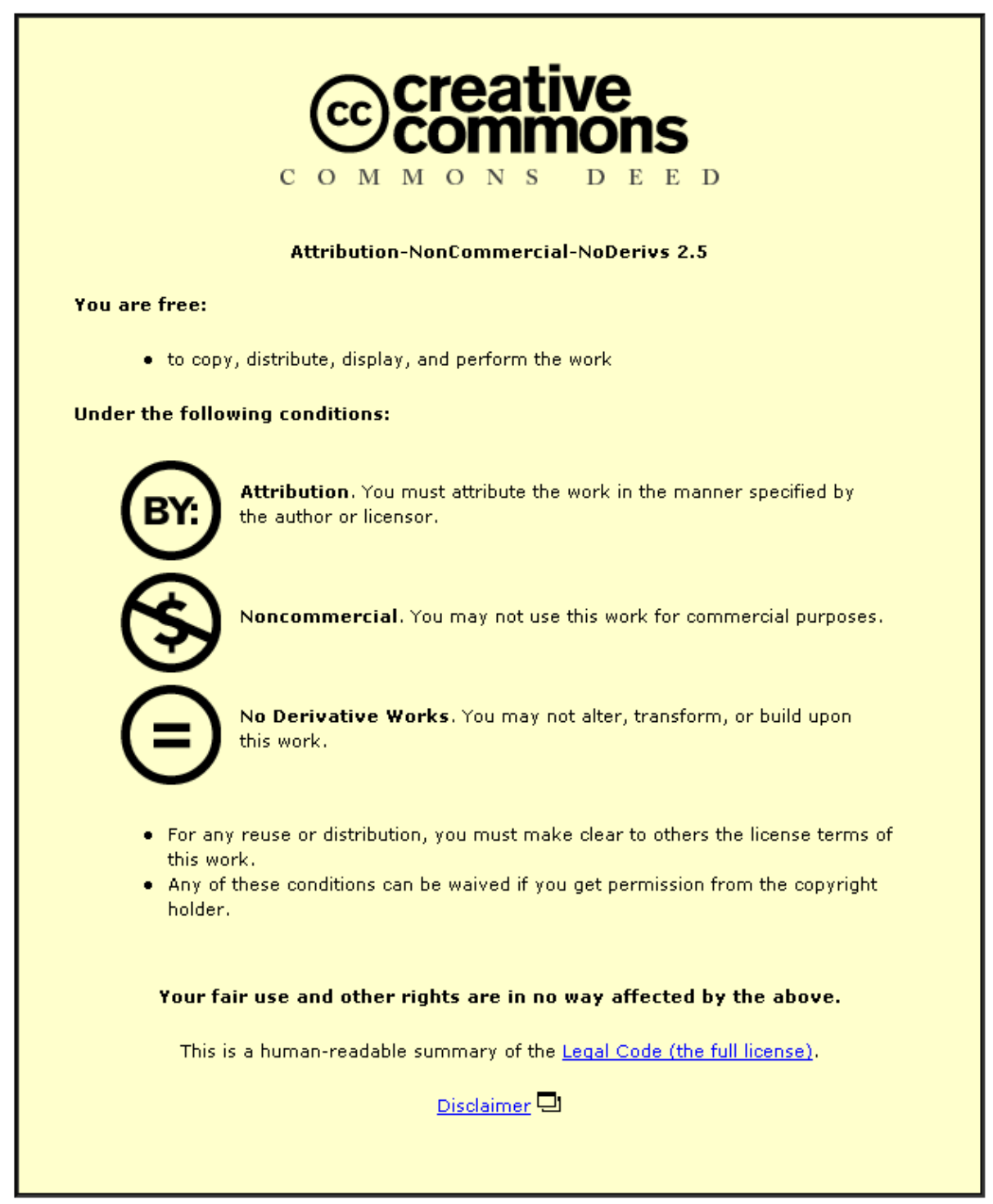

For the full text of this licence, please go to: http://creativecommons.org/licenses/by-nc-nd/2.5/ 


\section{Be Prepared: Communism and the Politics of Scouting in 1950s Britain}

\section{Sarah Mills}

To cite this paper:

Mills, S. (2011) Be Prepared: Communism and the Politics of Scouting in 1950s Britain, Contemporary British History 25 (3): 429-450

This article examines the exposure, and in some cases dismissal, of Boy Scouts who belonged or sympathised with the Young Communist League in Britain during the early 1950s. A focus on the rationale and repercussions of the organisation's approach and attitudes towards 'Red Scouts' found within their 'ranks' extends our understanding of youth movements and their often complex and conflicting ideological foundations. In particular, the post World War Two period presented significant challenges to these spaces of youth work in terms of broader social and political change in Britain. An analysis of the politics of scouting in relation to Red Scouts questions not only the assertion that British McCarthyism was 'silent', but also brings young people firmly into focus as part of a more everyday politics of Communism in British society.

Key Words: Communism, British McCarthyism, Cultural Cold War, Boy Scouts, Youth Movements

\section{INTRODUCTION}

The imperial sensibilities and gender-based politics of the Scout movement in Britain have been well studied by historians. There are, however, alternative stories and contestations within this youth organisation that have been marginalised in these histories and can provide an insightful counter-current to its dominant narratives. The Scout movement has, over time, been faced with a number of individuals in their 'ranks' who have professed beliefs and convictions that were seen to be unacceptable or antithetical to the purpose and character of its youth citizenship project. One such example has been a minority of Boy Scouts who held communist beliefs and belonged to the Young Communist League in the early to mid twentieth century. This article explores the case-study of 'Red Scouts' who were seen, most prominently in the early 1950s, as threats both to the ideological foundations of scouting and to other Boy Scouts. This minority of Red Scouts were also seen by some as symptomatic of a wider threat to the British nation and as such were ostracised and in some cases dismissed from the movement.

There are a number of reasons why this example is significant. Firstly, the historical context and time period when this minority of Red Scouts were active is important in terms of debates on British 'McCarthyism'. Whilst there was animosity between the Scout movement and Young Communist League in the 1920s, it was in the late 1940s and early 1950s that the issue of Red Scouts came to the fore. The subsequent witch-hunts and dismissals of these Red Scouts reveal a distinct 'McCarthyite' approach to communist youth in Britain. Therefore this article seeks to address a gap in the literature on the role of young people in this important period and consider them as part of a more everyday politics of communism in British society. 
Secondly, the ways in which scouting was thought about in the Post-World War Two period was influenced by an emerging youth culture and associated hopes and fears for British youth. 'Red Scouts' were seen as a threat and this example paints a bigger picture about 'appropriate behaviours' for youth in Britain at this time. Finally, through looking at this distinctive casestudy of 'Red Scouts' this article examines the politics of belonging to youth movements. This article discusses the formal politics of youth movement spaces as part of the reproduction of ideas of nationhood and citizenship, closely aligned with the state-project, alongside the everyday politics of how individual members have negotiated those meanings and practises. ${ }^{1}$ This case-study is an illustration of some of these tensions, made manifest in debates regarding 'difference' inside a youth movement that stresses sameness and a unified collective vision of British youth. Overall, this article argues that the everyday politics of belonging to a youth movement was, in the case of Red Scouts, more spectacular and extraordinary than the routine and mundane experiences which have tended to characterise the nostalgic and romanticized history of the Scout movement as 'part of the British way of life'.

This article is structured into four main sections. Firstly, I introduce youth movements and their institutional politics; secondly, I focus on the early history of the Scout movement and hostilities between various political factions, including the Young Communist League in the 1920s. In the third section, I focus specifically on the 1950s and the challenge the movement perceived from communist youth. The fourth section discusses the cases of two Boy Scouts dismissed for their communist beliefs and their appeals, as well as the response by the Communist Party of Great Britain and Young Communist League. In the conclusion, I reflect on what these case-studies mean for broader debates on British McCarthyism and the complex politics of youth movements.

\section{YOUTH AND INSTITUTIONAL POLITICS}

Youth has often been upheld as a powerful symbol of national strength, ambition and moral fortitude. ${ }^{2}$ Over time, and in a number of contexts, formal and informal attempts have been made by states to mobilise youth in support of national directives and wider (sometimes violent) political and social objectives. ${ }^{3}$ In Britain, a number of spaces were designed for young people in the late nineteenth and early twentieth century that aimed to foster ideas of patriotism, morality and good citizenship. ${ }^{4}$ These included schools, youth clubs, Sunday schools and, the focus of this paper, youth movements. Youth movements are volunteer-led informal spaces in civil society that, in the most part, were established by concerned or influential individuals to offer young people training in citizenship and moral values. Though their programmes varied, these were largely based on outdoor education, skills-based learning and uniformed discipline. Youth organizations such as the Boys' Brigade, Boy Scouts and Girl Guides have offered historians a lens through which to view changes in British society, though the focus in the literature has largely been on the origins and early formations of these organizations in early twentieth century Britain. ${ }^{5}$ Indeed, research on the Scout movement in Britain has remained firmly on the origins and interwar growth of the scheme. ${ }^{6}$

The post-World War Two period is an interesting turning point in the direction and motivations for many youth movements. This was a period of mass social change, none more so than for young people, and the ways in which this change was experienced by youth is crucial to our understanding of modern Britain. ${ }^{7}$ Bill Osgerby has argued how the emergence of youth as a new social category came to embody the hopes and fears of British society after $1945 .^{8}$ These fears were largely associated with emerging youth sub-cultures, increasingly 
perceived as a threat to the established social order and status quo in British society. Historical studies of British youth after the Second World War have tended to focus on these sub-cultures and this focus on 'folk devils' has somewhat overshadowed the distinct political and institutional engagements of youth at this time. ${ }^{9}$ There are some notable exceptions. Catherine Ellis has studied youth organizations run by political parties and party political relationships with youth after World War Two. ${ }^{10}$ These studies call into question the supposed apathy and dis-engagement of youth in political life in modern Britain. ${ }^{11}$ Furthermore, Lawrence Black has examined the Young Conservatives in 1950s and 1960s Britain, analysing their falling membership at this time and their political legacy. ${ }^{12}$ There is an important distinction to be made here, however, between youth-wings of political parties, such as the Young Conservatives and Young Communist League, and the phenomenon of uniformed youth organizations, the earliest forms of which were religious based organisations such as The Boys' Brigade (1883), Church Lads’ Brigade (1891), Jewish Lads' and Girls' Brigade (1895) and as the next section details, the Boy Scouts Association. ${ }^{13}$ In general, the former were structured around the principles of a political party and designed as a passage to adult party membership, whereas the latter were based around a particular ideological or religious belief. However, there were clearly crossovers in their motivations and philosophies. In sum, informal youth movement spaces and young-wings of political parties had different agendas and underlying philosophies and so their messages would, at times, have been conflicting, contradictory and problematic. The example in this article of a minority of young people who belonged to both the Scout Movement and the Young Communist League illustrates this argument about the tensions between formal political roles of youth movements and the everyday personal politics of its young members.

\section{THE POLITICS OF SCOUTING}

The Boy Scout Association (BSA) was founded by Robert Baden-Powell following a successful experimental camp on Brownsea Island, Dorset in 1907 and the popularity of Scouting for Boys, the self-instructor manual of his scouting method published in $1908 .^{14}$ The uniformed and outdoor-based programme of scouting was a massive success and its membership grew at a phenomenal rate both at home and abroad; today it is estimated that over 350 million people have, at some point, belonged to the Scout movement and it is now the largest youth organization in the world. ${ }^{15}$ Scouting was devised by Baden-Powell as an informal citizenship training scheme and was largely motivated by personal and societal fears over the moral and physical strength of British youth. The rationale of scouting to rejuvenate youth in the aftermath of the Boer War (1899-1902), in which Baden-Powell served, was steeped in fears over maintaining the British Empire, the Christian character of the nation and preserving the established social order. ${ }^{16}$ These fears over the future of the British nation and imperial project left in the hands of the next generation reveal how class-based politics were a part of the very foundations of the Scout movement.

The activities and philosophies of scouting were closely aligned to conservatism. Its institutional and representative politics were based on fierce loyalty to the state and the monarchy. Members were encouraged to participate politically through their duties as young citizens of helping others and demonstrations of patriotism such as parading at national events. The rationale for these activities was embodied in the Scout Promise to do one's duty to self, others and God. Yet despite these explicitly national and imperialistic objectives, Baden-Powell repeatedly stressed the 'non-political' character of his Scout movement. He steered clear of 
endorsing particular political parties, Boy Scouts were not to appear in uniform at political rallies or be seen to undertake 'official' government work, for example strike-breaking. These attempts to remain neutral were further complicated when, at specific points, the movement encountered individuals who embodied a particular kind of politics deemed unacceptable to its ideological foundations and at odds with its citizenship model. Indeed, a number of tensions and 'battlegrounds' emerged in scouting's early history, particularly during the interwar period, relating to accusations of militarism and fascism from pacifists. ${ }^{17}$ The alternative views of a minority of pacifist Scout leaders were problematic to scouting's hierarchy and there were dismissals. John Hargrave, prominent Scouter and HQ Commissioner for Camping and Woodcraft, was removed from the organisation following his unconventional views on the direction scouting should take after World War One. He established an alternative youth movement - the Kibbo Kift Kindred - in 1920 and whilst a relatively unpopular movement that folded in 1951, it can be seen as the predecessor for other pacifist-inspired movements including the Woodcraft Folk, a left-wing youth organisation established by Leslie Paul in $1925 .{ }^{18}$ The Folk were also closely linked to the Young Pioneers movement and had markedly different positions on issues such as religion and mixed-sex provision compared to early youth organisations, and scouting in particular. In this article, I want to illustrate an argument about the continued politics of scouting using another example of hostilities from scouting's past. A small number of 'Red Scouts' at different points in time are an example of a group whose beliefs were viewed as an antithetical counter-current to scouting's (non)-political character. They were individuals whose scout-uniformed presence questioned the very fundamentals of scouting philosophy and troubled the adult vision of an 'ideal' future British citizenry. Furthermore, as 'insiders', they were viewed by some as having the potential to influence other Boy Scouts and guide them in alternative teachings and practises, contradicting the messages and particular brand of scouting which the establishment viewed as vital to the moral fortitude and stability of Britain and her Empire.

The first tensions emerged in the 1920s with a sustained attack on the Scout movement by the Young Communist League (YCL). The youth-wing of the Communist Party of Great Britain (CPGB) was founded in 1921 and was an important part of the Party's political ambitions. $^{19}$ In its earliest years, the YCL viewed Baden-Powell's scheme as a militaristic exploitation of the working class and campaigned against it between 1921 and 1927; they completed their drive by sending the Chief Scout a small cardboard coffin intended to symbolize the death of the Scout movement. ${ }^{20}$ At an institutional level, Baden-Powell had exchanged several letters with William Rust, National Secretary of the YCL, on the motivations and methods of scouting. B-P refused to debate these in public and defended his Scout Movement, in particular that his fund to raise $£ 50,000$ for Boy Scouts in London was in no way asking 'wealthy citizens' to fight communism and to 'poison the minds of the young workers' as Rust had earlier claimed. ${ }^{21}$ Although the publicity campaign of the YCL was widespread, it was ultimately overshadowed by scouting's popularity and growth during interwar Britain. Baden-Powell condemned their attacks, but was far more concerned with the isolated cases of ‘infiltration’ by communist youth into Scout troops. In 1922 the Chief Scout described how:

Three Rovers [Scouts aged over 15] were actually led to forget their Scout Promise and were persuaded to try and spread Communist ideas among the Scouts in their District.

But the [other] Scouts were true to their honour, and reported matters to their Scoutmaster, so that the Rovers concerned were requested to leave the Movement. ${ }^{22}$ 
Although there were no direct rules on communism in scouting policies, these boys were judged to have broken their Scout Promise and asked to leave. In the quotation above, Baden-Powell was warning against the specific risk posed by communist youth inside the movement, but was also positioning other Boy Scouts as defenders of the movement and sent a clear message that it was part of a scout's duty and honour to 'be prepared' to encounter and expose these troublesome and disruptive political individuals. The three Rovers in 1922 were the only officially reported case of such 'attacks' in the interwar period. This example nevertheless demonstrates the repercussions on individual Scouts who professed beliefs deemed antithetical to the character of the wider movement.

\section{BRITISH MCCARTHYISM AND THE RED (SCOUT) MENACE}

During the late 1940s and early 1950s, the self-professed 'non-political' Scout movement became increasingly active and interested in the political opinions of its young members and adult leaders. These activities can be seen as part of a 'British McCarthyism' which aimed to expose and castigate those with communist connections. ${ }^{23}$ Anti-Communist campaigns and tactics in Britain during the late 1940s and early 1950s have been described as a 'silent' McCarthyism characterised by purges of communists and sympathisers, particularly in governmental jobs, but with less panic and more tolerance than in the United States. ${ }^{24}$ MI5 and the Information Research Department (IRD), established within the Foreign Office in 1948, targeted members of the CPGB and those with communist connections including government officials, intellectuals, politicians, churchmen, BBC personnel, folk-singers and entertainers. ${ }^{25}$ Where youth was involved, the risk of communist infiltration was deemed by some to be much greater to society due to the symbolic role of youth in the life of the nation. Educational spaces such as universities and organizations such as the World Federation of Democratic Youth (WFDY), a left-wing youth organisation founded in London in 1945, were therefore closely monitored by government departments, though the focus was largely on adults who could influence young minds, rather than on young people themselves. ${ }^{26}$ Academic literature on British McCarthyism has expanded recently from examining state-level anti-communist practises towards a wide range of sites and settings in civil society. There has been an increasing focus on what has been termed the 'everyday' politics of communism in British society and the 'cultural Cold War'. ${ }^{27}$ Scouting is one example that shows how not only state apparatus were involved in 'McCarthyite' activities, but that institutions in civil society were also part of the everyday politics of communism in Britain.

The 1950s were a difficult and challenging time for the Scout organisation. They were suffering from the loss of male leaders and prominent Headquarters personnel following World War Two and beginning a lengthy domestic re-building and fundraising programme. Furthermore, this period was also marked by a changing relationship with empire. As previously discussed, one of the traditional concerns of the Scout Movement was the defence of the British Empire, prompting the YCL to attack the Scouts in the 1920s as part of their anticolonial campaigns. The 1950s marked a period of de-colonisation and therefore this period of upheaval in the British Empire resonated through the Scout Movement as it considered questions over its role, purpose and position in this new landscape. Most significantly, the organisation was still struggling to come to terms with the death of Baden-Powell in 1941 and finding suitable 'replacements' for the Chief Scout.. Furthermore, whilst searching for stability and new growth, the organisation was also encountering an emerging youth culture and changes in employment and leisure time. ${ }^{28}$ The advent of the 'teenager', associated moral panics, and 
the new economic and social freedoms of young people living in Britain was beginning to impact the way the movement thought about its members. In the midst of these changes, therefore, scouting and its rationale of improvement and moral fortitude was seen by its supporters to be needed more than ever. As such, Young Communists that the organisation encountered in the early 1950s were positioned as a direct threat to all that was seen as stable and 'good' about the movement.

The BSA's fears over the threat communism posed to young members became increasingly apparent in the late 1940s. The Committee of the Council requested recommendations from its internal Boy Scout and Girl Guide Religious Panels in 1948 on the 'Christian answer to Communism' and a joint committee was established in 1950 'to consider ways of advising Scouters' - the term which refers to all adults in scouting. ${ }^{29}$ The discussions of this committee resulted in the publication of A Challenge to Scouting: The Menace of Communism in $1951 .{ }^{30}$ Whilst there were earlier 'battlegrounds' between scouting and political factions in previous decades, the existence of a specific commissioned booklet on communism is significant. Its stated purpose was to:

remind Scouters of the fundamental beliefs of Scouting over which there can be no compromise, and to ask them to ensure that their Scouts are well founded in these beliefs by the time that they go out to work, for it is then, that the full challenge of the world may meet them for the first time. ${ }^{31}$

The booklet positioned communism as completely incompatible with scouting and claimed that they were 'diametrically opposed to each other'. ${ }^{32}$ This pamphlet justified the incompatibility through the Scout law and promise - the verbal declaration and individualized commitment a young person made when they joined the movement and the schema through which the tenets of good citizenship were communicated. The booklet argued that firstly, communists professed

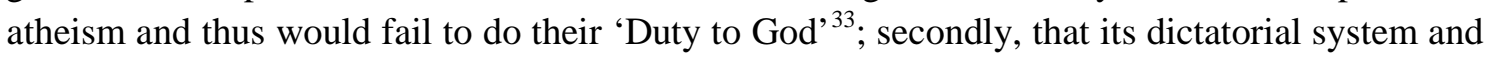
opposition to constitutional democracy would mean a failure to do their 'Duty to The King'; and that finally, there would be an overall failure to keep the Scout Law. The booklet suggested further reading from Christian publications as well as reports made by the Church of Scotland, and was intended as a forewarning for adults in scouting to be aware of the dangers its young members faced. ${ }^{34}$ It failed to acknowledge however, that Scouts themselves could be supporters of communism, with the challenge seen as coming from outside the movement. Between the time the booklet was commissioned and published, however, this scenario of an 'inside' threat had become a reality.

In 1950, Jeffrey Hinkinson, a seventeen year old Scout from West Bromwich in the West Midlands was dismissed from the $93^{\text {rd }}$ Birmingham Scout Group for collecting over two hundred signatures for a peace petition and later admitting he had communist sympathies. ${ }^{35}$ At the time, this story gained little press attention, and that mostly of a light-hearted dismissive character, with a local newspaper commenting that 'no-one is seriously going to suggest that a boy of 17 is a political menace, and that he should be shunned by all society!' ${ }^{36}$ Hinkinson had no official connection to the YCL, but was dismissed by his local scoutmaster (whose decision was final), the case further confirming to the BSA that its prepared booklet should be widely distributed the following year. The most prolific 'Red Scouts' would, however, appear a few years later and open up the issue of communism for wider debate as they were more politically active than Hinkinson and had stronger connections to the YCL. Though a handful of 
individual cases, the emergence of 'Red Scouts' was significant enough to create a much wider and far-reaching debate about appropriate political behaviours and lifestyles of young people in the early 1950s.

\section{‘LITTLE RED RIDING HOOD’ AND ‘A CASE OF PINK MEASLES’}

Two celebrated and 'model' Boy Scouts were both exposed as communists in their respective Scout Groups in Bristol and Birmingham during 1954. This section explores the two cases and the character and repercussions of their exposure. There were also different outcomes: one Red Scout was expelled indefinitely and constructed as a hidden and cloaked threat, and the other Red Scout was seen as a confused adolescent, described by a local newspaper as having 'pink measles' ${ }^{37}$ Through this discussion, I highlight how these two cases challenged ideas about scouting in the 1950s and reflected broader concerns about British youth at this time. I also show how the CPGB, through the YCL, used this campaign as part of a broader push to attack the Scout Movement. Although the Red Scouts affair was in many respects limited to these two cases, these examples are significant enough to enable a discussion of the broader politics of scouting and the CPGB during this period. Both cases prompted extreme responses from the BSA and, particularly in the case of the Bristol Scout, a national debate in the House of Lords and a banned BBC broadcast. It is hard to ascertain the wider scale and scope of communist sympathisers across the BSA; indeed, no survey or report was commissioned by the movement. However, smaller local press stories such as Hinkinson's and others exposing Scout Leaders during this period, suggests that this issue stretched further than these two important and detailed case-studies.

On 9 February 1954, Paul Garland, a nineteen year old toolmaker from Bristol, was interviewed for the Western Daily Press following his appointment as the new District Secretary for the West of England YCL. The article stated that 'Communism is not the only cause in which Paul Garland is active' and listed his other interests, which included scouting. ${ }^{38}$ Garland had been part of the $5^{\text {th }}$ Bristol (St. Luke's, Brislington) Scout Group since the age of eight and had achieved the highest award for young people in scouting - The Queen's Scout Award. Though his communist leanings had been known to his Scoutmaster for a number of months, the institutional confirmation of his political beliefs through his new role in the YCL was deemed to be a step too far. A number of national newspapers ran with the story in the following days, quoting high-ranking officials of the BSA who stated: 'Paul will not be sacked, he will just cease to be a Scout'. ${ }^{39}$ These reports, however, were rumours and conjecture as only his local Scout Group could officially dismiss him. On 11 February, a scout-uniformed Garland defiantly attended his local Scout group's pantomime - Little Red Riding Hood - and gave a press interview stating that he intended to appeal any potential dismissal. A few days later, Garland received a letter from his Group Scoutmaster, S. H. Wilkinson, stating that 'for reasons which must now be apparent to you I give you formal notice... of your dismissal...I must ask you to return your badges'. ${ }^{40}$ Although the decision was made and upheld in Bristol, it was backed by Chief Scout Lord Rowallan - only the second Chief Scout to be appointed since the death of Baden-Powell. Garland's expulsion caused a divide within the BSA, with letters of support and condemnation sent to Headquarters. The case was closely followed in the weeks running up to the appeal, particularly as the YCL mounted an immediate campaign to reverse Garland's dismissal, picketing the Chief Scout outside scouting rallies and publishing position pieces in their journal Challenge. ${ }^{41}$ A number of leaflets were published by the YCL and there were regular articles in the CPGB daily newspaper The Daily Worker, one of which stated that 
'nothing could make more clear the whole Tory bias of the action of the BSA' ${ }^{42}$ Garland also recorded an interview defending his dual membership as part of a regional television programme The Week in the West, though this was controversially cancelled by the BBC the night before it was due to air following complaints from a number of Conservative MPs, with the Director General of the BBC later stating 'it would be a mistake to allow the broadcast to take place'. ${ }^{43}$ An editorial opinion in the Manchester Guardian remarked how:

We had the hysterical spectacle...of the whole weight of the Tory Party machine being rushed into action to get banned a West Region interview with the boy in which, in perfect fairness, the BBC was to present also the views of Boy Scout headquarters. ${ }^{44}$

This reaction is perhaps emblematic of the BBC's policy on communism at the time, but also challenges the non-political character and supposed impartiality of this British institution, instead highlighting its perceived role as the 'voice' of the establishment. ${ }^{45}$ Paul Garland's campaign was also taken up by William Wedgwood Benn (Viscount Stansgate), following his son, the Labour (and later socialist) MP Anthony Benn's criticisms of the BSA from his constituency of Bristol South East. ${ }^{46}$ In a debate that would last over four hours, Viscount Stansgate tabled the motion 'that in the opinion of this House the imposition of political and religious tests by the Boy Scout Movement is foreign to its Charter and purpose and repugnant to our national tradition of liberty and conscience'. ${ }^{47}$ Despite this public and political support, albeit in the minority, Garland's appeal in Bristol a few days after the Lord's Debate failed, with the Group Committee 'satisfied that the enquiry was properly constituted and conducted and accordingly the decision that his dismissal by his GSM [Group Scoutmaster] should be upheld is final'. ${ }^{48}$ After the appeal, Garland stated that 'my loyalty to the Scouts has never been questioned. I am grieved at the way things have gone. This means that my association with the movement has now finally ended. ${ }^{49}$

A variety of reasons were given by local and national scouting bodies to justify Garland's exclusion. Whilst there were some technical explanations given - including his age and the lack of a Senior Scout section for him to attend - it was Garland's YCL membership and communist beliefs that appeared to have made him a 'bad' Scout unworthy of membership. Their condemnation stemmed from Garland's inability to keep the Scout Promise, drawing on ideas of incompatibility outlined in A Challenge to Scouting published a few years earlier. Supporters of the decision argued that 'no man can serve two masters so entirely opposed to each other ${ }^{\text {' }}$ and rallied 'if he's sincere in that [communism] he obviously cannot be a sincere Scout. Let him - make him - make his choice. ${ }^{51}$ A spokesperson from the BSA stated that 'although the Boy Scout Movement is non-political, the question boils down to this: can a member [of the YCL] faithfully fulfil his Scout's promise to do his Duty to God and the Queen?'52 This official response also suggested to other Boy Scouts that the authorities would somehow be monitoring and passing judgement over whether the promise they once made as a child was being kept. Clearly moves towards adopting an informal version of anti-communist 'McCarthyite' policies employed by formal state structures were troubling to some adults in scouting. One Scout Leader writing in the Bristol Evening World asked:

Are you [other] Scout leaders prepared to paint your pointed Scout hat midnight black and sit on the investigating committee prodding broomsticks into any of us who - you might care to think - have slipped up on the oath? ${ }^{53}$ 
This case also highlights debates on the liberty of the individual, and how the movement responded to accusations of restrictions on individual beliefs. Supporters of Garland maintained that political affiliation was the concern of the individual, and not that of the BSA. J. H. Martin, an Assistant District Commissioner for scouting in Wiltshire, argued that 'I also fail to see any rule....referring to persons [sic] political views, except that in uniform they do not participate. And if Communist boys are barred, why not Conservatives, Liberals and Labour? ${ }^{54}$ Mr Martin had raised a valid point: the rules of the BSA made no reference to specific political parties, or indeed the YCL, but took exception to political activities more generally. However, the BSA's actions in expelling Garland effectively stated that a Boy Scout was never politically independent of the collective body, and that even if the individual was not in uniform, they were still representative of the wider Scout movement.

In contrast to the BSA's position on the incompatibility of scouting and communism, Garland stated numerous times in written statements and at press briefings that he believed scouting and communism were compatible and could even be seen as having similar ideals and a joint ability to unite youth and fight injustice. Writing to Chief Scout Rowallan in Garland's defence, the National Secretary of the YCL John Moss stated that:

There is no question of Mr. Garland's deep interest, activity and loyalty to the Scout Movement as those of us in the YCL who have known him for a number of years can personally bear out. We believe that it is quite possible for a young person to be a Scout and a Communist, and, in point of fact, many people are. ${ }^{55}$

I would argue that the YCL clearly had their own objectives in using the Garland case to boost their own membership numbers and expose what they saw as the class-consciousness and conservatism of the Scouts. However, unlike the 1920s when the YCL positioned themselves as the complete alternative to scouting, here the YCL stressed that the two organisations were compatible in fostering a young person's sense of self, values and beliefs. ${ }^{56}$ For example, in one of their pro-Garland pamphlets, the YCL maintained that 'Scouts and young Communists have similar ideas of world youth friendship and brotherhood...But many working class lads leave the Scouts because they have little say in running the organisation. ${ }^{57}$

Garland was constructed, particularly by the Chief Scout, as a danger to the reputation and success of scouting's citizenship training scheme. Presented as a troublesome and politicized youth, whose behaviours and style of political participation were seen as divergent from those of the 'good' ideal Boy Scout, Garland had ultimately undermined scouting's role as the producer of good young British citizens. And yet, Garland had kept his two activities separate and investigations carried out by the BSA showed he had not tried to influence other Boy Scouts or distribute material. The Daily Worker challenged Rowallan's position, stating that 'he does not quote any instance of Paul spreading anti-religious propaganda among his scout troop. He does not quote Paul as urging his friends to betray their Queen or country. He cannot - because he knows Paul has never done these things' ${ }^{58}$ Official statements from the BSA and Lord Rowallan used various loosely-defined sources of communist material as evidence to highlight the militant atheism of the YCL and thus Garland's corroboration in such activities. In a circular of 'facts' to all County Commissioners, District Commissioners and their assistants, Chief Executive Commissioner A.W.Hurll stated that: 
As an official, he [Garland] is bound by the discipline and rules of the Communist Party. The Charter of the YCL requires Young Communists to conduct anti-religious propaganda. It is clear from these extracts that Paul Garland...cannot sincerely keep the Scout Promise. ${ }^{59}$

Much of this evidence and literature had been sent to the BSA from individuals and outside sources, including the Economic League, and had been misquoted or wrongly attributed to the YCL. This was a matter of great frustration to National Secretary John Moss who wrote to Chief Scout Rowallan asking him 'to retract the statements you have so mistakenly attributed to the YCL', something the Chief Scout never did. ${ }^{60}$ Furthermore, several press stories suggested Garland was planning to become an adult leader, and therefore he became positioned as an immediate and exaggerated (adult) threat to other Boy Scouts, drawing on existing fears over the susceptibility of young minds. Indeed, Lord Rowallan stressed that 'surely, we are not to keep one boy, whom we have lost all hope of helping, and at the same time, risk the danger of harming those others whom we are leading to a belief in God? ${ }^{61}$ This episode then can be seen as a 'moral panic' in action, an internal fear that became embodied in this one Boy Scout. This panic was fuelled by editorial and public opinion, in particular from Christian publications. One parent wrote in The Catholic Times that 'it seems nothing short of duty on the part of Catholic parents to keep their boys away from a movement in which their faith may be jeopardized. ${ }^{62}$

The case, and its associated moral panic, was also used by the BSA and its supporters to make a wider point about the nature of communist activities and tactics in everyday British society. Garland's return to scouting after a temporary absence from attending night school in the previous months was seen by many as a planned infiltration and political stunt. Chief Scout Lord Rowallan argued that 'The Communists have deliberately persuaded this boy to appear suddenly in Scout uniform and so force us to take action against him'. ${ }^{63}$ Described as a 'deliberate plant ${ }^{64}$, though there was no evidence for this, Garland became emblematic of a wider communist threat to British values and society. Many, such as the late Robert BadenPowell's own son, believed this was part of a much longer campaign whereby 'the Communists endeavour to infiltrate their agents into scouting and other youth organisations for their own insidious ends'. ${ }^{65}$ This familial connection mobilised many within the Scout movement to rally a call to 'be prepared' against such infiltration. One Scout group in Cardiff stressed the need to be 'on guard' and had 'no doubt that some directive will go out to our brother Scouts everywhere to be on the alert against the next attack, which will surely be made against our principles, from some other quarter, and in a more crafty manner' ${ }^{66}$ During the Lords debate, much discussion was given to Paul's potential hidden role as part of the wider Communist Party:

No one is better placed...than the Communist who has been through the Scout Movement. He may cloak his identity by using the Scout Movement as a cover, or, by declaring it, he may try to bring contempt on...the Scout Movement...which he is supposed to serve. ${ }^{67}$

Garland was also seen by several Lords as part of a wider diseased communist threat that could contaminate the British nation. Geographers such as Tim Cresswell and David Sibley have examined the way disease metaphors have been used to engender fear and legitimate persecution, exclusion and stereotypes of difference. ${ }^{68}$ Examples of this metaphorical use can be 
seen in the way Garland was described in the Lords debate by Viscount Buckmaster who maintained that 'a Communist within the ranks of any other society is merely the parasite feeding on the body of its host which it will ultimately and certainly destroy' ${ }^{69}$ He continued by making reference to countries in the Soviet Bloc where Scouts were experiencing discrimination and described cases of infiltration as 'a new form of bacteriological warfare'. ${ }^{70}$ Paul Garland was therefore seen by several high-ranking scout officials and supporters as a real threat to the vitality and existence of the Scout movement. His presence and representative politics were seen as 'out-of-place' and threatening to the wider collective body of Scouters. As suggested earlier, this response was perhaps a manifestation of scouting's anxieties over the end of empire and Britain's international standing. Whilst there is no evidence of dismissals and exposures from other scouting nations, these fears can also be seen in the press coverage from other countries battling with 'the menace of communism'. For example, Garland's dismissal was featured in TIME magazine in the US and the Canadian Press in particular followed the story closely, with one editorial from the Chronicle Telegraph in Quebec stating that the 'exclusion of Garland is undoubtedly a wise move...the Scouting movement aims to produce good citizens, and its members deserve to be protected from damaging influences'. ${ }^{71}$ There was, however, a very similar example of another communist Boy Scout in Britain that hit the headlines in the same month as Paul Garland that reveals the complexities of the everyday and localised politics of scouting.

Richard Etheridge, a twenty year old Scout from Birmingham and member of the YCL, had written to the local Birmingham Gazette in support of Garland following his dismissal. The letter was never published, however the newspaper then exposed Etheridge as a 'Red Scout' in a separate article and his Scout Group began an investigation. It emerged that Etheridge's communist views had been known to his Scout Group following his trip to the World Youth Festival in Berlin in 1951. On his return, he was threatened with expulsion, but allowed to stay. This second incident in 1954 of support for Garland was taken more seriously and again divided opinion internally on how to 'deal' with difference in terms of the political opinions of Boy Scouts. As with Garland, the YCL defended Etheridge's dual membership, with Colin Williams, secretary of the Midlands YCL, stating that 'we deplore this attack on the sacred rights of an individual to follow whatever political and religious beliefs he may have' ${ }^{72}$ The County Commissioner for scouting in Worcestershire, Captain Spreckley, discussed the case with the District Commissioner for Halesowen, and after considering local circumstances and private discussions, Etheridge was allowed to stay. His local Scoutmaster, Mr Tromans, explained how:

Although Etheridge did wrong in putting the troops [sic] name to the letter, I feel it was a mistake any young person might have made in a misguided attempt to follow his convictions. All other Rovers in the troop have been questioned and I am satisfied that there has been no attempt on Etheridge’s part to spread Communism among them. ${ }^{73}$

Again, the construction of other Boy Scouts as either potential vulnerable targets, or as insiders who could expose a Red Scout, is demonstrated in this example. . The YCL used Etheridge's reprieve to strengthen Garland's case, stating that: 'The Scout officials in Birmingham have acted in a more sensible way than those who were still insisting on the expulsion of Paul Garland. The decision to allow Dick E. to stay in the Scouts is a victory for democracy and a blow against the witch-hunt. ${ }^{74}$ However, although there was very little difference between the 
technicalities of the two cases, Etheridge won his appeal and Garland lost. This contradictory position created difficult questions for the BSA and Chief Scout Rowallan in particular. His official response was that:

There is no inconsistency. In the case of Etheridge, the Scouters of his Group, all of whom know him well, are satisfied that he is able to carry out his Promise...It is with him a struggle between loyalties in which we can help him. On the other hand, Paul Garland has been carefully chosen by the YCL as a member of their National Executive and Secretary of their West of England Branch. By accepting these posts, he is pledged to active work for Communism, and the Scouters of his Group are convinced that he is in no position to fulfil his Scout Promise. ${ }^{75}$

There is a further point to make here about internal governance and accountability in scouting. This bureaucratic inconsistency highlights the differential ways that those close to the boys at a grassroots level thought about their Scouts in an everyday sense, the embodied ways they were willing to overlook political affiliation or difference - compared to that of the Chief Scout who saw himself as the central figure and emblematic of the bigger picture regarding the organisation's status and standing. These dynamics have changed over time, yet there are still varying levels of bureaucracy in scouting at local, regional and national levels that often prompt calls to re-assess the governance of the organisation. At the time of the Red Scouts affair, there were calls to re-assess scouting's aims and constitution, with one Scout Leader suggesting to Headquarters that:

We ought, I am convinced, to take a deep breath and seriously re-examine our methods and aims... I feel we must keep such thoughts [of the Law and Promise] before us all the time to ensure that scouting lives with the times and does not become, like its headgear, a left-over from the past. ${ }^{76}$

There are a number of parallels here with other organisations, not least established political parties, who in the mid to late 1950s were re-assessing their position, aims and methods to attract youth in an increasingly changing world.

In the earlier quote from Lord Rowallan, we can also see how Etheridge was not considered a threat, but rather a confused boy who needed his Scout group as a space to reform. Scouters claimed he was a confused adolescent struggling to position himself between his parents' ideological beliefs. His mother was heavily involved in her local Church and a staunch Conservative, describing her son as a good Christian Scout 'prepared to fight for his country'. ${ }^{77}$ However, his father was an active and influential member of the Communist Party and Amalgamated Engineering Union as part of his role as convener of shop stewards at Longbridge motor works. ${ }^{78}$ Etheridge's local scouting authority were offering to steer him back along the 'right path', and this further marginalised Garland as a working-class communist youth without the external moral influences of the familial home and the Church. Little is known about Richard Etheridge after his dismissal and there are no records of his involvement in the YCL after his reprieve. However, Paul Garland never returned to scouting and remained a committed member of the YCL, writing in Challenge a number of times on various subjects including the anti-apartheid movement. He became the founder chairman of the Bristol Tbilisi Association creating a twinning agreement between Bristol and Tbilisi in Georgia, where he had visited as 
part of the YCL many years before. He went on to become an enthusiastic Labour Supporter and City Councillor and was Deputy Mayor of Bristol at the time of his death in 1999.

\section{CONCLUSION: THE HEART OF BRITISHNESS}

In this article, I have made an argument about the formal politics of youth movement spaces as part of the reproduction of ideas of nationhood and citizenship and the everyday politics of how individual members have attempted to challenge and negotiate their meanings and practises. I have also shown how 'rival' youth organisations, in this case the YCL, perceived scouting and used the Red Scouts affair as an important cultural battleground in the early Cold War era. The case studies presented here are an example of the everyday cultural politics of communism in Britain in the early 1950s and enhance our understanding of the nature, scale and scope of British anti-communism during this period. The press coverage the cases received highlights the interest and public furore over 'Red Scouts', as does the almost daily correspondence to Headquarters on the issue during the spring of 1954. The actions of the BSA further demonstrate that it was not only government departments who were occupied in the exposure of communists, but 'ordinary' spaces and institutions in civil society, and in this case, one entwined with ideas of loyalty, patriotism and good citizenship. In terms of the character of British McCarthyism, it is, however, clearly a pale shadow of the US version; and yet it could be argued more controversial in its application as the focus here was on young people. The example of Red Scouts in the 1950s also highlights a much broader attitude to the 'Red Menace' during this period. Viscount Alexander of Hillsborough, speaking in the Lords Debate on Garland, described the Scouts as '....emblematic, a metaphor for, the British nation: if the Communists could infiltrate the Scouts - they were at the heart of what is seen to be British' ${ }^{79}$ Indeed, many believed that if communists could 'get into' or 'appear' within this institution which embodied Britishness and the character of the nation, then nothing was sacred. If Red Scouts had been ignored, many believed the Scout movement would have been metaphorically permitting and tolerating a wider infiltration of communism into British society. Those who complained at the treatment of Red Scouts, however, were making a broader point about questions of liberty, tolerance, and warning over 'treading the downward path that will bring us to the sorry state of modern America'. ${ }^{80}$ Viscount Stansgate, in particular, used the example of Garland's exclusion to make a much wider argument about how British society was going to accommodate people that held communist views. The Lords debate failed to tackle this issue and Viscount Stansgate eventually withdrew his motion, outnumbered by his peers; instead, the debate was used to reaffirm Anglo-American relations, with Earl Winterton commenting that 'I hope the enemies of Communism abroad and our friends in the United States will be encouraged by this debate'. ${ }^{81}$

The Scout movement has always been seen as a stronghold of established social order and representative of an idealistic and nostalgic vision of British youth. As this article has shown, the 1950s were a time when the organisation, already struggling for stability and postwar direction, encountered direct challenges from 'alternative' visions of scouting. An individual or group who represented a threat or counter-narrative to its politics, such as Red Scouts, was either seen as a threat to be removed or as a challenge for the organisation to reform. This approach by the BSA is significant as the Scout movement had continually defined itself as 'non-political'. Indeed, although Robert Baden-Powell did not endorse party politics, the approach to 'Red Scouts' both during his leadership and afterwards was 
intrinsically political as an attempt to preserve established social order. The witch-hunts in the early 1950s made an example out of Red Scouts and set the future direction of the Scout movement during the Cold War. The scenario of other 'political' youth dismissed from the BSA did not occur again, however the BSA was still keen to push and circulate anti-communist messages well into the 1960s and fears over the Red Menace still concerned the International Department at the BSA. During the 1960s, the Foreign and Commonwealth Office supplied the BSA with unpublished booklets entitled International Communist Front Organisations, amongst others, which they stated 'we are allowed to give...to a few people outside the Service who would find them useful'. ${ }^{82}$ These fears did, however, have to be reconciled during the development of scouting in the Soviet Union in the latter half of the twentieth century. Throughout the 1960s and beyond, other changes were implemented to the programme, uniform and membership structure of the Scout Movement in Britain. For example, in 1976 the first moves towards co-education were taken, with the late twentieth century characterised by dismissals of girls who claimed a place within scouting and whose actions eventually led to a change in policy to include both boys and girls. ${ }^{83}$ Indeed, it is widely acknowledged by historians who have studied the Scout movement that one of the tensions at the heart of its project has been how to acknowledge and accommodate difference within an organization that stresses sameness and uniformity as a collective body of youth. There are, therefore, alternative stories of contestation, negotiation and exclusion which have ruptured the youth citizenship project of the Scout movement. Whilst these more subtle politics have lain beneath the surface of their organization during the last century, what was unique in the early 1950s was that these politics became visible, explicit and transferred directly onto the party political views of its members.

\footnotetext{
${ }^{1}$ This is characterised in debates within political geography as the distinction between Politics (with an upper-case ' $\mathrm{P}$ '), concerned with the formal political organizations and processes of the state, and politics (with a lower-case 'p'), which refers to personal politics or everyday politics of identity, see Philo and Smith, 'Guest Editorial', 99-115; Flint, 'Dying for a P', 617-620.

${ }^{2}$ On the changing definitions and debates on youth, see Gillis, Youth and History; Valentine, 'Boundary crossings', 37-52.

${ }^{3}$ Koon, Believe, Obey, Fight; Kater, Hitler Youth.

${ }^{4}$ See, for example, Ploszasjka, 'Moral landscapes', 413-29.

${ }^{5}$ On British youth movements, see Springhall, Youth Empire and Society; Wilkinson 'English Youth Movements', 3-23;

${ }^{6}$ On the Boy Scout Movement, and sister organization the Girl Guide Movement founded in 1910, see Proctor, On My Honour; Proctor, '(Uni)Forming Interwar Youth', 103-134; Warren 'Sir Robert BadenPowell', 376-398; Warren, 'Mothers of the Empire', 96-109; Rosenthal, The Character Factory. For a detailed biography of Robert Baden-Powell, see Jeal, Baden-Powell.

${ }^{7}$ For histories of youth culture and British society, see Fowler, Youth Culture in Modern Britain; Stainton Rogers, 'Making and Moulding of Modern Youth', 1-9.

${ }^{8}$ Osgerby, Youth in Britain. It is worth noting here however, that there is a much broader history of youth culture and indeed other historical periods can be seen as influential in the development and characterization of youth. See, for example, Savage, Teenage.

${ }^{9}$ Cohen, Folk Devils.

${ }^{10}$ Ellis, 'No Hammock for the Idle', 441-470; Ellis, ‘The Younger Generation', 199-231.

${ }^{11}$ See also Abrams and Little, 'The Young Activist', 325-7.

12 Black, 'The Lost World of Young Conservatism', 991-1024.

${ }^{13}$ Springhall, Fraser and Hoare, Sure and Stedfast; Kadish, A Good Jew and a Good Englishman.
} 
${ }^{14}$ On the early origins of Scouting and Baden-Powell's Scouting for Boys, see Boehmer, 'Introduction' xi-xxxix.

${ }^{15}$ For a comprehensive overview of work on scouting history and its various international and post-

colonial contexts, see Proctor and Block, Scouting Frontiers.

${ }^{16}$ See Boehmer, 'Introduction', pp.xii-xxvii

${ }^{17}$ On some of these issues, see Dedman, 'Baden-Powell, Militarism', 201-23. On pacifism more broadly, see Ceadel, Pacifism in Britain.

${ }^{18}$ Davis, Fashioning a New World; Prynn, 'The Woodcraft Folk', 79-95

${ }^{19}$ On the YCL see Linehan, Communism in Britain; Beckett, Enemy Within; Fishman, The British

Communist Party; Andrews, Fishman and Morgan, Opening the Books; Morgan, Cohen and Flinn, Communists and British Society.

${ }^{20}$ Scout Association Archive (hereafter SAA) PWE/8/34, Robert Baden-Powell, Chief Scout to Percy William Everett, Deputy Chief Scout, 25 December 1927.

${ }^{21}$ SAA/TC/109/Communism, William Rust, YCL to Lt General Sir Robert Baden-Powell, 17 October 1927.

22 'Chief Scout’s Outlook', Headquarters Gazette, September 1922.

${ }^{23}$ The term McCarthyism emerged soon after Senator Joseph McCarthy's speech in West Virginia on 9 February 1950 when he accused the State Department in the US of harbouring over two hundred communists. The phrase, however, refers more broadly to Cold War anxieties originating in the late 1930s and lasting well into the term of Richard Nixon. See Fried, McCarthyism; Shrecker, The Age of McCarthyism.

${ }^{24}$ On British McCarthyism, see Potter, 'British McCarthyism’, 143-157; Parsons, 'British McCarthyism and the Intellectuals', 224-246; Hollingsworth and Tremayne, The Economic League.

${ }^{25}$ Defty, Britain, America and Anti-Communist Propaganda; On 'blacklisted' communists, see Harker, 'The Manchester Rambler', 219-228; Harker, Class Act.

${ }^{26}$ Parsons, 'British McCarthyism', 235

${ }^{27}$ For an excellent summary of work on the cultural and everyday history of the Cold War, see Shaw, 'Britain and the Cultural Cold War', 109-115; Paris, 'Red Menace!', 117-132; Kirby, 'Ecclesiastical McCarthyism', 187-203.

${ }^{28}$ On the 'cult' of youth and sub-cultures in the 1950s and 1960s, see Hall and Jefferson, Resistance Through Rituals; Bugge, 'Selling Youth', 185-202; Booker, The Neophiliacs.

${ }^{29}$ Girl Guide Association Archive, Minutes of the Religious Panel, 67, 13 February 1950, no.4, 2.

${ }^{30}$ An identical version entitled A Challenge to Guiding: The Menace of Communism was published by the Girl Guide Association in 1951.

${ }^{31}$ Boy Scout Association, A Challenge to Scouting: The Menace of Communism London, 1951, 2.

${ }^{32}$ Boy Scout Association, Challenge to Scouting, 7.

${ }^{33}$ The Scout movement's relationship with religion and the evolution of 'Duty to God' is complex. The Founder maintained that belief in a higher power was central to a young person's development, but was adamant that boys of all religious beliefs could promise to do their duty to their God. See Mills, 'Youth Citizenship and Religious Difference', 190-206.

${ }^{34}$ On The Church of Scotland Report on the Communist Challenge to Christian Youth, see McFarland and Johnston, 'The Church of Scotland's Special Commission', 337-361.

35 ، "Red” Boy Scout is Thrown Out', Daily Express, 12 August 1950.

36 'Notes and Comments', West Bromwich Free Press/Midland Chronicle, 18 August 1950.

${ }^{37}$ 'Red Scouts', Birmingham Mail, 12 March 1954.

38 'Bristol Communist Leader who is a Queen’s Scout!', Western Daily Press (Bristol), 10 February 1954.

39 'Can a Communist b2e a true Scout?', Evening Standard, 10 February 1954.

${ }^{40}$ Parliamentary Archives, Westminster Papers of Viscount Stansgate, ST/131/408, S.H.Wilkinson, Group Scoutmaster of $5^{\text {th }}$ Bristol (St. Luke’s, Brislington) Scout Group to Paul Garland, 15 February 1954.

${ }^{41}$ Untitled, Challenge, 20 February 1954

${ }^{42}$ Scouts or Tories?, Daily Worker 15 February 1954

${ }^{43}$ BBC Written Archive, Caversham Park, Reading, Berkshire, R34/313/4 - Policy: Communism 19521955, Sir Ian Jacob, Director General of the BBC to Mr Crouch, MP for North Dorset, 23 February 1954.

44 'Personally Speaking', Reynolds News, 19 February 1954.

${ }^{45}$ See Fairlie, 'The BBC', 175-192.

46 'Red Scout - The Chief will talk today’, Daily Express, 13 February 1954. 
${ }^{47}$ Viscount Stansgate, Parliamentary Debates (Hansard) The House of Lords Official Report, Vol. 186, no.46, 11 March 1954, 299.

${ }^{48}$ SAA/TC/109/Paul Garland, Press Statement of Boy Scout Association, 2 April 1954.

49 'Expelled Scout loses his appeal', The Star, 2 April 1954.

${ }^{50}$ SAA/TC/109/Paul Garland, Rex Hazelwood, Editor of The Scout, to Mr. M. Joseph, 24 February 1954.

${ }^{51}$ SAA/TC/109/Paul Garland, 'Hawkeye’ to Boy Scout Association, 7 March 1954.

52 'Scout is Communist Secretary', The Star, 10 February 1954.

53 'The Red Scout - Saturday Talking Point', Bristol Evening World, 13 February 1954.

${ }^{54}$ SAA/TC/109/Paul Garland, J. H. Martin to Boy Scout Association, 25 February 1954, original emphasis.

${ }^{55}$ Archive of the Communist Party of Great Britain (hereafter ACPGB), CP/CENT/YOUTH/04/10 (19271954), John Moss, National Secretary of YCL, to Lord Rowallan, Chief Scout, 11 February 1954.

${ }^{56}$ For more on the wider attitudes and politics of CPGB and YCL towards youth cultures and social movements more broadly, see Dworkin, Cultural Marxism and Callaghan, Crisis, Cold War and Conflict.

${ }^{57}$ Young Communist League (1954) Paul Garland: Good Scout, Good Communist

58 'BE PREPARED - but NOT for a PURGE', Daily Worker 20 February 1954

${ }^{59}$ SAA/TC/109/Communism, Circular, A.W.Hurll, Chief Executive Commissioner of BSA to County and District Commissioners, 17 February 1954.

${ }^{60}$ ACPGB, CP/CENT/YOUTH/04/10 (1927-1954), John Moss, National Secretary of YCL, to Lord Rowallan, BSA, February 15 1954; SAA/TC/109/Paul Garland File, J. Baker White, Economic League to BSA, March 11954.

${ }^{61}$ Lord Rowallan, Parliamentary Debates (Hansard) The House of Lords Official Report, Vol. 186, no.46, 11 March 1954, 318.

62 'Catholics and Scouting’, Catholic Times, 12 March 1954.

63 'Row over Scout “a red stunt” ' Sunday Chronicle, 14 February 1954.

${ }^{64}$ Lord Rowallan, Parliamentary Debates (Hansard) The House of Lords Official Report, Vol. 186, no.46, 11 March 1954, 315.

${ }^{65}$ Lord Baden-Powell (Peter Baden-Powell), Parliamentary Debates (Hansard) The House of Lords Official Report, Vol. 186, no.46, 11 March 1954, 336.

${ }^{66}$ SAA/TC/109/Paul Garland, Cardiff West Scout Group to Boy Scout Association, 12 March 1954.

${ }^{67}$ Viscount Buckmaster, Parliamentary Debates (Hansard) The House of Lords Official Report, Vol. 186, no.46, 11 March 1954, 341.

${ }^{68}$ See Cresswell, 'Weeds, Plagues', 330-345 and Sibley, Geographies of Exclusion.

${ }^{69}$ Viscount Buckmaster, Parliamentary Debates (Hansard) The House of Lords Official Report, Vol. 186, no.46, 11 March 1954, 340.

${ }^{70}$ Viscount Buckmaster, Parliamentary Debates (Hansard) The House of Lords Official Report, Vol. 186, no.46, 11 March 1954, 345.

71 'Communist Cannot Be A Boy Scout' Quebec Chronicle Telegraph17 February 1954; see also 'Little Red Eagle Scout’ TIME, 22 February 1954.

72 'Now Another Scout Comes Under Fire', Daily Worker, 17 February 1954

${ }^{73}$ ACPGB, CP/CENT/YOUTH/04/10 (1927-1954), Page of typed notes on Etheridge Case, 1 March 1954.

${ }^{74}$ ACPGB, CP/CENT/YOUTH/04/10 (1927-1954), handwritten note by John Moss, National Secretary of YCL, undated.

${ }^{75}$ SAA/TC/109/Paul Garland, A.W. Hurll, Chief Executive Commissioner of BSA to all County Commissioners, 15 March 1954.

${ }^{76}$ SAA/TC/109/Paul Garland, C. R. Waller to BSA, 22 February 1954.

77 ، “Perhaps I Was Weak - Scout Chief’, Birmingham Mail, 16 February 1954.

${ }^{78}$ Richard Albert Etheridge Papers (MSS.202), Modern Records Centre, University of Warwick

${ }^{79}$ Viscount Alexander of Hillsborough, Parliamentary Debates (Hansard) The House of Lords Official Report, Vol. 186, no.46, 11 March 1954, 353.

${ }^{80}$ SAA/TC/109/Paul Garland, M. Pates to Boy Scout Association, 12 February 1954.

${ }^{81}$ Earl Winterton, Parliamentary Debates (Hansard) The House of Lords Official Report, Vol. 186, no.46, 11 March 1954, 325-6.

${ }^{82}$ SAA/TC/109/Communism/General Correspondence on Communism Folder, Foreign and Commonwealth Office to BSA

${ }^{83}$ See Mills, 'Scouting for Girls?', forthcoming. 


\section{References}

Abrams, Philip, and Alan Little. 'The Young Activist in British Politics'. British Journal of Sociology 16, no. 4 (1965): 325-7.

Andrews, Geoff, Nina Fishman and Kevin Morgan, eds. Opening the Books - Essays on the Social and Cultural History of the British Communist Party London: Pluto Press, 1995.

Beckett, Francis. Enemy Within: The Rise and Fall of the British Communist Party London: John Murray, 1995.

Boehmer, Elleke. 'Introduction’. In Scouting for Boys: A Handbook for Instruction in Good Citizenship, original version Robert Baden-Powell. Oxford: Oxford University Press, 2004 [1908].

Booker, Christopher. The Neophiliacs: A study of the revolution in English life in the fifties and sixties London: Fontana Collins, 1969.

Black, Lawrence. 'The Lost World of Young Conservatism'. The Historical Journal 51, no.4 (2008): 991-1024.

Bugge, Christian. 'Selling Youth in the Age of Affluence: Marketing to Youth in Britain since 1959'. In An Affluent Society? Britain's Post-War Golden Age Revisited, edited by Lawrence Black and Hugh Pemberton. Burlington, VT; Aldershot: Ashgate, 2004.

Callaghan, John. Crisis, Cold War and Conflict: The CPGB 1951-1968 London: Lawrence and Wishart, 2003.

Ceadel, Martin. Pacifism in Britain 1914-1945: The Defining of a Faith Oxford and New York: Oxford University Press, 1980.

Cohen, Stanley. Folk Devils and Moral Panics London: MacGibbon and Kee, 1972.

Cresswell, Tim. 'Weeds, Plagues and Bodily Secretions: A Geographical Interpretation of Metaphors of Displacement'. Annals of the Association of American Geographers 87, no.2 (1997): 330-345.

Davis, Mary. Fashioning a New World: A History of the Woodcraft Folk Loughborough: Holyoake Books, 2000.

Dedman, Martin. 'Baden-Powell, Militarism and the 'Invisible Contributors' to the Boy Scout scheme, 1904-1920’. Twentieth Century British History 4, no.3 (1993): 201-23.

Defty, Andrew. Britain, America and Anti-Communist Propoganda: The Information Research Department 1945-53 London; New York: Routledge, 2003.

Dworkin, Dennis. Cultural Marxism in Postwar Britain: History, The New Left and the Origins of Cultural Studies Durham, NC: Duke University Press, 1997.

Ellis, Catherine. 'No Hammock for the Idle: The Conservative Party, 'Youth' and the Welfare State in the 1960s’. Twentieth Century British History 16, no.4 (2005): 441-470.

Ellis, Catherine. 'The Younger Generation: The Labour Party and the 1959 Youth Commission'. Journal of British Studies 41, no. 2 (2002): 199-231.

Fairlie, Henry. 'The BBC’. In The Establishment, edited by Hugh Thomas. London: Anthony Blond, 1959. 
Fishman, Nina. The British Communist Party and the Trade Unions (1933-1945) Aldershot: Scholar Press, 1995.

Flint, Colin. 'Dying for a “P”? Some Questions Facing Contemporary Political Geography’. Political Geography 22, no.6 (2003): 617-620.

Fowler, David. Youth Culture in Modern Britain c.1920-c.1970: From Ivory Tower to Global Movement: A New History. Basingstoke: Palgrave Macmillan, 2008.

Fried, Albert. McCarthyism: The Great American Red Scare - A Documentary History, New York, Oxford: Oxford University Press, 1997.

Gillis, John. R. Youth and History: Tradition and Change in European Age Relations, 1770-Present. New York; London: Academic Press, 1974.

Hall, Stuart, and Tony Jefferson, ed. Resistance Through Rituals: Youth Subcultures in Post-war Britain London: Hutchinson, 1976.

Harker, Ben. 'The Manchester Rambler’: Ewan MacColl and the 1932 Mass Trespass’. History Workshop Journal 59, no.1 (2005): 219-228.

Harker, Ben. Class Act: the Cultural and Political Life of Ewan MacColl. London: Pluto Press, 2007.

Hollingsworth, Mark, and Charles Tremayne, The Economic League: The silent McCarthyism, London: National Council for Civil Liberties, 1989.

Jeal, Tim. Baden-Powell London: Pimlico, 1991.

Kadish, Sharman. A Good Jew and a Good Englishman: The Jewish Lads’ and Girls’ Brigade 1895-1995 London: Valentine Mitchell, 1995.

Kater, Michael. H. Hitler Youth. Cambridge, MA: Havard University Press, 2004.

Kirby, Dianne. 'Ecclesiastical McCarthyism: Cold War Repression in the Church of England' Contemporary British History 19, no.2 (2005): 187-203.

Koon, Tracy H. Believe, Obey, Fight: Political Socialization of Youth in Fascist Italy, 1922-1943. Chapel Hill: University of North Carolina Press, 1985.

Linehan, Thomas P. Communism in Britain 1920-39: from the cradle to the grave. Manchester: Manchester University Press, 2007.

McFarland, Elaine.W, and Ryan J. Johnston, 'The Church of Scotland’s Special Commission on Communism, 1949-1954: Tackling 'Christianity’s Most Serious Competitor' Contemporary British History, 23, no.3 (2009): 337-361.

Mills, Sarah. 'Youth Citizenship and Religious Difference: Muslim Scouting in the United Kingdom'. In Scouting Frontiers: Global Youth and the Scout Movement's First Century, edited by Tammy Proctor and Nelson Block. Cambridge: Cambridge Scholars Press, 2009.

Mills, Sarah. 'Scouting for Girls? Gender and the Scout Movement in Britain'. Gender Place and Culture 18, no. 4 (2011): 537-56.

Morgan, Kevin, Gidon Cohen and Andrew Flinn, ed. Communists and British Society 1920-1991: People of a Special Mould, London: Rivers Oram Press, 2007.

Osgerby, Bill. Youth in Britain since 1945. Oxford: Blackwell, 1998. 
Paris, Michael. 'Red Menace! Russia and British Juvenile Fiction'. Contemporary British History 19, no.2 (2005): 117-132.

Parsons, Steve. 'British McCarthyism and the Intellectuals'. In Labour's Promised Land? Culture and Society in Labour Britain 1945-1951, edited by Jim Fyrth. London: Lawrence \& Wishart, 1995.

Philo, Chris, and Fiona M. Smith. 'Guest Editorial: Political geographies of children and young people'. Space and Polity 7, no.2 (2003): 99-115.

Ploszasjka, Teresa. 'Moral landscapes and manipulated spaces: gender, class and space in Victorian reformatory schools’. Journal of Historical Geography 20, no.4 (1994): 413-29.

Potter, Karen. 'British McCarthyism’. In North American Spies: New Revisionist Essays, edited by Rhodri Jeffreys-Jones and Andrew Lownie. Edinburgh: Edinburgh University Press, 1991.

Proctor, Tammy M., and Nelson R. Block, ed. Scouting Frontiers: Global Youth and the Scout Movement's First Century. Cambridge: Cambridge Scholars Press, 2009.

Proctor, Tammy M. On My Honour: Guides and Scouts in Interwar Britain Philadelphia: American Philosophical Society, 2002.

Proctor, Tammy M. '(Uni)forming Youth: Girl Guides and Boy Scouts in Britain, 1908-39’. History Workshop Journal 45, spring (1998): 103-134.

Prynn, David. 'The Woodcraft Folk and the Labour Movement 1925-70'. Journal of Contemporary History 18, no.1 (1983): 79-95.

Rosenthal, Michael. The Character Factory: Baden-Powell and the Origins of the Boy Scout Movement New York: Pantheon Books, 1986.

Savage, Jon. Teenage: The Prehistory of Youth Culture 1875-1945. London: Penguin, 2008.

Shaw, Tony. 'Introduction: Britain and the Cultural Cold War' Contemporary British History 19, no.2 (2005): 109-115.

Shrecker, Ellen. The Age of McCarthyism: A Brief History with Documents. Boston: St. Martin’s Press, 1994.

Sibley, David. Geographies of Exlcusion. London; New York: Routledge, 1995.

Springhall, John. Youth, Empire and Society: British Youth Movements 1883-1940 London: Croom Helm, 1977.

Springhall, John, Brian Fraser, and Michael Hoare. Sure and Stedfast: A History of the Boys' Brigade 1883-1983. London: Collins, 1983.

Stainton Rogers, Rex. 'The Making and Moulding of Modern Youth: a short history'. In Youth In Society, edited by Jeremy Roche, Stanley Tucker, Rachel Thomson and Ronny Flynn. London; Thousand Oaks, CA; New Delhi: SAGE, 2004.

Valentine, Gill. 'Boundary Crossings: transitions from childhood to adulthood'. Children's Geographies 1, no.1 (2003): 37-52.

Warren, Allen. 'Sir Robert Baden-Powell, The Scout Movement and citizen training in Great Britain 1900-1920’. English Historical Review 101 (1986): 376-398. 
Warren, Allen. 'Mothers of the Empire’? The Girl Guides Association in Britain 1909-1939’. In Making Imperial Mentalities: Socialization and British Imperialism, edited by J.A. Mangan. Manchester: Manchester University Press, 1990.

Wilkinson, Paul. 'English Youth Movements, 1908-30'. Journal of Contemporary History 4, no.2 (1969): 3-23. 